\title{
American Psychiatry in Transition: Reform or Revolution?
}

\section{By Lucas Richert and Matthew DeCloedt*}

\section{Introduction}

In 1969, the American Psychiatric Association (APA) held its annual meeting at the stylish Americana Hotel in sunny Miami, Florida. As participants registered the temperature hovered around 25 degrees Celsius, but there was tension in the air. Several protestors walked along Miami Beach and loitered outside the hotel, while some licensed and more militant members of the APA were gearing up to make waves during the conference.

The throng of radical psychiatrists at the APA meeting in 1969 exemplified tensions within the mental health field and typified divisions in American society. They argued that the field of mental health needed to transform its training, methodology, and service delivery models. It had to throw off neutrality and embrace individual and collective sickness, which some contended were natural byproducts of militarism, alienation, and racism. 'Therapy means political change', the radical psychiatrists averred at the end of the 1960s, not 'peanut butter', meaning that mental health was intimately tied to social transformation. ${ }^{1}$ Only through the latter, they believed, could mental illness be prevented.

Yet, self-described radicals were not always at the forefront of reformist agendas and far from the only health providers to conceive of society as sick. Liberals, as opposed to 'radicals', contributed to the restructuring of mental health care services in the 1950s-1960s by championing

\footnotetext{
* Lucas Richert is a Lecturer in History at the University of Strathclyde. He is the author of Conservatism, Consumer Choice, and the FDA during the Reagan Era: A Prescription for Scandal and Strange Medicines: Drugs, Science, and Big Pharma in Culture. Matthew DeCloedt (BA, Hons, JD) has contributed to the Sloane Letters Project and is an LLM student at Central European University. 1 Jerome Agel, ed., The Radical Therapist: The Radical Therapist Collective (New York: Ballantine Books, 1971), viii-xi. Why peanut butter was chosen remains an open question. Successful therapy, however, required social, political, and personal change.
} 
social psychiatry and preventive psychiatry. ${ }^{2}$ Adherents of both sought to locate the mental patient (and their symptoms) within a broader socio-political context. Additionally, both strains of reformers interrogated the health of American society. Given two world wars and a history of slavery and discrimination, it was worthwhile re-evaluating psychiatry's traditional role and thinking more critically about a 'sick society'. ${ }^{3}$ Though radicals and reformers-professional and lay-agreed widely on the diagnosis of the problem, their prescriptions were often fundamentally opposed.

\section{Background}

The federal government got much more involved in psychiatric reform during the 1960s. The passage of the Community Mental Health Centers (CMHC) Act in 1963 culminated nearly two decades of excitement in the mental health field. The legislation offered federal subsidies for the construction of CMHCs, which were intended to be the foundation of a 'radically new policy'. In addition to CMHCs, Medicaid, Social Security Disability Insurance (SSDI), Supplementary Security Income (SSI), and other resources enabled persons with serious mental disorders to reside in the community. These efforts seemed to work, at least initially, and hospital populations dropped swiftly. Ideas about reform therefore stretched back to the early 1960s and extended beyond labels of 'radical'.

By the 1970s, the US mental health system was comprised of multiple, intersecting institutions: short-term mental hospitals, state and federal long-term institutions, nursing homes, residential care facilities, CMHCs, outpatient departments of general hospitals, community-based programs, residential institutions, and client-run and self-help services, among others. Structures and legislation, in other words, impacted and influenced mental health theory and practice. ${ }^{4}$

\footnotetext{
${ }^{2}$ Melvin Sabshin, Changing American Psychiatry: A Personal Perspective (Washington, D.C.: American Psychiatric Publishing, 2008), 266.

${ }^{3}$ Sandra L. Bloom, Creating Sanctuary: Toward the Evolution of Sane Societies (New York: Routledge, 2013), 114.

${ }^{4}$ Gerald N. Grob, ‘Public Policy and Mental Illnesses: Jimmy Carter's Presidential Commission on Mental Health,' The Milbank Quarterly 83, no. 3 (2005): 425-456.
} 
But change would not have been possible without the 'rights revolution' of the 1960 s and 1970s. The starting point was the drafting in 1970 of twenty-six such rights by the National Welfare Rights Organization, which led to the American Hospital Association's 1973 'Patient's Bill of Rights'. These were momentous in that they declared that a patient could refuse treatment as well as 'obtain from his physician complete current information concerning his diagnosis, treatment, and prognosis, in terms the patient can be reasonably expected to understand ${ }^{5}{ }^{5}$ More broadly, orthodox thought behind personal well-being, health, and psychic security was destabilized in a climate of political insecurity that witnessed 'the rise of libertarian models and conservative politics in the United States' ${ }^{6}{ }^{T}$ These social and cultural changes manifested in medicine and the medical marketplace. Citizens formed alliances against the Cancer Establishment and created a cancer counterculture, a pushback against the rich and powerful. Some, who felt they were being bullied by elites, relied on home remedies, others on quackery or folk wisdom, while other groups employed old-fashioned religious faith. ${ }^{7}$ Not anti-science per se, these belief systems constituted a reassessment of the purely biomedical model.

The era was uniquely emotive. Fears abounded - of the sexual revolution, an eroding economy, a political system in disarray, of the dénouement of American supremacy. It was a moment of 'testing for Americans', many of whom had come to 'fear that the nation had lost its ability to master its problems'. For many, America had reached a threshold, its people and government on a cliff's edge. Observers 'began to talk of an American climacteric, of a sclerotic society irreversibly succumbing to the ravages of age' ${ }^{8}$ Put more bluntly: the US was going down the drain. Mental health and psychiatry reflected this state of affairs: a mix of hope and scepticism,

\footnotetext{
${ }^{5}$ Lewis A. Grossman, 'The Rise of the Empowered Consumer,' Regulation 37, no. 4 (Winter 2014-2015), 36.

${ }^{6}$ Dan Carpenter, Reputation and Power: Organizational Image and Pharmaceutical Regulation at the FDA (Princeton, NJ: Princeton University Press, 2010), 730-731. See Philip Jenkins, Decade of Nightmares: The End of the Sixties and the Making of Eighties America (New York: Oxford University Press, 2006).

7 James T. Patterson, The Dread Disease: Cancer and Modern American Culture (Cambridge: Harvard University Press, 1989), ix.

${ }^{8}$ Robert M. Collins, Transforming America: Politics and Culture During the Reagan Years (New York: Columbia University Press, 2007), 7.
} 
doggedness and resignation. Some radicals in the psy-sciences preferred to tweak orthodoxies, operate within the system, and play with mental health classifications; others wanted a new age entirely and pursued mind-expansion in the treatment room and beyond. Some practitionersadvocating explicitly psychedelic approaches to mental health-quoted William Blake: 'If the doors of perception were cleansed, everything would appear to man as it is, infinite. ${ }^{9}$ Many mental health radicals believed this to be a truism. With the right treatment, no limits constrained the US or its citizens. Mental illness could be prevented, treated, and even cured.

The mental health arena also witnessed new entrants, with the rise of patient groups, new therapies tailored for mass consumption, and the continuance of psychedelic psychiatry. ${ }^{10}$ Patientconsumers could dip their toes into New Age medicine, draw from naturopathy and homeopathy, and engage in Eastern-influenced medicine or teachings from sources like the Esalen Institute in California. They might sample alternative mental health therapies, such as Primal Scream Therapy or Transactional Analysis, or find psychic solace in the form of new religious movements. Americans began running for body and spirit, struck yoga poses, and hit discotheques to allay their emotional anxieties. Individuals, it was posited, could prevent mental health problems from materializing by taking control of their life.

What of practitioners themselves? Various authors had sporadically suggested that mental health professionals were nebbish and cloistered. Robert Coles suggested that psychiatrists 'try to hide behind our couches, hide ourselves from our patients', and prolong 'the very isolation often responsible for our patients' troubles' ${ }^{11}$ According to writers in the American Journal of

\footnotetext{
9 James H. Austin, Zen-Brain Reflections: Reviewing Recent Developments in Meditation and States of Altered Consciousness (Cambridge, Mass.: MIT Press, 2006), 296.

${ }^{10}$ Judi Chamberlin, 'The Ex-Patients' Movement: Where We've Been and Where We're Going,' Journal of Mind and Behaviour 11, no. 3 (1990): 323-364; Grossman, 'The Rise of the Empowered Consumer'; David Herzberg, 'Blockbusters and Controlled Substances: Miltown, Quaalude, and Consumer Demand for Drugs in Postwar America,' Studies in History and Philosophy of Biological and Biomedical Sciences 42, no. 4 (2011): 415-26; Erika Dyck, Psychedelic Psychiatry: LSD from Clinic to Campus (Baltimore: Johns Hopkins University Press, 2008).

${ }^{11}$ Robert Coles, 'Young Psychiatrist Looks at His Profession,' The Atlantic Monthly, July 1961, 108-111.
} 
Orthopsychiatry, psychiatrists shunned the possibility of 'broad social change' and 'passionate political involvement' for a variety reasons, including professional insulation, a preoccupation with prestige, and an infatuation with methodology. ${ }^{12}$ Bruno Bettelheim called psychiatrists 'a rather conservative group', which tended to avoid 'radical analysis' of society's problems, let alone entertain 'radical solutions'. ${ }^{13}$ To these critics, psychiatry was at risk of becoming irrelevant if it did not engage with the wider world.

\section{Radical Origins}

Raymond Waggoner, the president of the 16,000-member strong APA in 1968, was in touch with the times. 'Change', he asserted, was 'a catchword in American life' and his intention was to oversee 'healthy and wisely determined progress' ${ }^{14}$ He suggested that the APA be more active and take a diversified role in social problems outside of institutional structures. Psychiatrists and mental health organizations, he argued, must agree to take responsibility for social change and social issues. It just so happened that the APA was in the process of modifying its Constitution, with amendments that called for a more 'action-oriented role' for psychiatrists. ${ }^{15}$ Instead of 'furthering the study of the nature, treatment, and prevention of mental disorders', the new language indicated efforts 'to improve the treatment, rehabilitation, and care of the mentally ill...and the prevention of psychiatric disabilities' ${ }^{16}$ Overall, he felt, 'as psychiatrists, we should not be afraid to be social activists' and that it was 'time to make concrete plans for psychiatry's more constructive role in our future society'. ${ }^{17}$ This was the 'establishment'?

\footnotetext{
12 Frank Riessman and S.M. Miller, 'Social Change Versus the "Psychiatric World View,"' American Journal of Orthopsychiatry 34, no. 1 (1964): 29-38.

${ }^{13}$ Bruno Bettelheim, 'Review of Committee on Social Issues, Psychiatric Aspects of the Prevention of Nuclear War,' Bulletin of the Atomic Scientists 21, no. 6 (1965): 55-56.

14 'Perspectives for the APA Under the New Constitution, 1968,' Raymond Waggoner Papers, 1926-1977, Correspondence, Folder 2, Bentley Historical Library, University of Michigan, 2.

${ }^{15}$ Ibid, 15-16.

${ }^{16}$ Ibid, 13. See also 'American Psychiatric Association: The Constitution,' American Journal of Psychiatry 125, no. 3 (1968): 434-a-439.

${ }^{17}$ Raymond W. Waggoner, 'Facing the Challenge of Today,' Hospital \& Community Psychiatry 20, no. 10 (1969), 298 and Raymond W. Waggoner and Raymond Waggoner Jr., 'Psychiatry in the Modern World,' Current Psychiatric Therapies 9 (1969), 9.
} 
Ideologically, radicals in the APA latched onto notions of parochialism, conservatism, and neutrality. These concepts were anathema to their ideas regarding prevention and intervention, but they were not alone in their views. By 1969, the American Orthopsychiatric Association, American Academy of Psychoanalysis, and the Group for the Advancement of Psychiatry (GAP) had already proven sensitive to pressing social problems. The same was true of the APA and American Psychoanalytic Association (APsaA). Wider public engagement was palpable in the pages of the American Journal of Psychiatry and Psychiatric News as well as in the formation of standing committees on such topics as aggression, foreign affairs, and poverty. One AJP article, by Walter $\mathrm{E}$. Barton, argued that while the landscape in which psychiatry operated was different, not all psychiatrists wished 'to participate in the social evolution and revolution that are today's reality'. He cautioned against over-enthusiasm for 'new fashions' in psychiatry, even as he remarked that numerous vital issues, including gun violence, needed increased attention. ${ }^{18}$ The APsaA, for its part, established a Standing Committee on Social Psychiatry in 1969, something that had not previously interested practicing analysts. 'Inaction', it seemed, was no longer an acceptable approach for psychiatry. Instead, the concept of neutrality was increasingly viewed as anachronistic and a possible cause of the field's decline. ${ }^{19}$

The radicals first coalesced at the APA's 1968 annual meeting in Boston as 'Psychiatrists for Action on Racism and the Urban Crisis'. During the May gathering, concern 'about the grave social conditions in the nation', the 'danger of riots', and 'the effects of racism and poverty on the social and emotional well-being of the entire country' resounded. ${ }^{20}$ By most accounts, the group was

\footnotetext{
${ }^{18}$ Walter E. Barton, 'Prospects and Perspectives: Implications of Social Change for Psychiatry,' American Journal of Psychiatry 125, no. 2 (1968): 147-150.

19 'The Death of Inaction,' Psychiatric News, October 1968. Some excellent examples of psychiatry's engagement with the wider world include: Bryant Wedge, 'Training for a Psychiatry of International Relations,' American Journal of Psychiatry 125, no. 6 (1968): 731-36 and Howard P. Rome, 'Psychiatry and Foreign Affairs: The Expanding Competence of Psychiatry,' American Journal of Psychiatry 125, no. 6 (1968): 725-730.

${ }^{20}$ Richard Morrill, 'Ad Hoc Committee for Social Action,' May 15, 1968, MS Coll 641, Box 61, Folder 735, Walter J. Lear Health Activism Collection, Annenberg Rare Book \& Manuscript Library, University of Pennsylvania [hereafter WJLHAC] and idem, 'Psychiatrists for Action on Racism and the Urban Crisis,' May 15, 1968, MS Coll 641, Box 61, Folder 735, WJLHAC.
} 
finding its feet and brainstorming about goals. On May 15, a set of radical psychiatrists supportive of 'social action' in 'urban and racial' relations met to discuss how to improve American communities. Four specific topics were addressed: (I) Working with 'grass-roots' groups; (II) Emergency care in violent outbreaks; (III) Changing white racism; and (IV) Education and careers. Tackle the social origins of mental illness, they surmised, and it could be prevented. Part laundry list of member activities and part 'how-to' manual for engaging with the critical issues of social movements and racism, the aim of the meeting was to create awareness of the practicalities involved in psychiatric activism.

In San Francisco, for instance, psychiatrists had 'developed a working relationship' with the Black Panther movement. This took the form of offering political support when Black Panther candidates ran for office and delivering medical and psychological services during demonstrations. The practical lesson to be drawn was that mental health providers should 'make oneself available...with these local groups'. To be more successful with grassroots interactions it was 'best to let the initiative come from them as to the role to be played by the medical or psychiatric personnel'. This way, 'maximum autonomy and power' would 'remain in the hands of the community group' ${ }^{21}$

This first iteration of radical psychiatry thus engaged with the issues of social justice and the social determinants of health, but eschewed direct criticism of the profession and did not adopt a revolutionary ethos. Instead, its philosophy emphasized the need for more 'grass roots education organization' and increased work 'within communities' ${ }^{22}$ While the liberal caucus demanded more APA involvement in the contemporary issues of the day, debate was relatively polite and no one displayed overt hostility. According to a psychiatrist from Boston, who also served as recording secretary for the group in 1968, 'two directions of action were agreed on: a petition at the

\footnotetext{
${ }^{21}$ Morrill, 'Ad Hoc Committee for Social Action.'

${ }^{22}$ Nathan Hurvitz, 'The Status and Tasks of Radical Therapy,' Psychotherapy: Theory, Research, and Practice 14, no. 1 (1977), 70.
} 
convention to give immediate expression to the opinions of many attending, and long term activities within the APA itself'. ${ }^{23}$ The APA's tepid response to radicalism suggests it was more concerned with keeping things as they were than transforming their policy and preventing mental illness, contrary to what was suggested in its new Constitution.

By 1971, psychotherapist Claude Steiner, having already positioned himself as an organizer and thought leader, offered a breakdown of 'squares' and radicals in mental health. His taxonomy reduced practitioners to distinct subsets and provided a means to understand their disputes, simultaneously obfuscating and explaining radicalism. In Steiner's estimation, Alpha psychiatrists, the largest segment in the profession, were liberal/conservative in their 'political consciousness' and in 'practice and methods of psychiatry'. The establishment, in short, that he wished to overthrow. Beta psychiatrists were similarly liberal/conservative in their politics, although these individuals employed radical methods and techniques such as group counselling or the unsanctioned use of drugs. By contrast, Steiner's third category, the Gamma psychiatrist, was radical in politics and traditional in their everyday practice and treatment of patients. Here, anti-psychiatrists R.D. Laing and Thomas Szasz served as examples since they employed 'old, outmoded methods of therapy based on Freudian or neo-Freudian therapy'. The fourth and final type of psychiatrist, a Delta, was radical politically and in psychiatric practice. ${ }^{24}$ Unfortunately, intra-radical conflict precluded Steiner's practitioner-types from uniting as a bloc and carrying out a unified program.

\section{Publication Record}

Radicals in mental health were provided a forum to discuss their principles and practices in 1970 when Michael Glenn, a United States Air Force psychiatrist in Minot, ND, initiated a Radical Therapist Collective and started The Radical Therapist journal. An idea spawned during the cold North Dakota

\footnotetext{
23 Ibid.

${ }^{24}$ Claude Steiner, 'Radical Psychiatry: Principles,' edited by Agel, The Radical Therapist, 1 and 3.
} 
winter, Glenn wanted his publication to be a fiery 'rallying ground' to help develop a therapy 'that serves the people'. ${ }^{25}$ However, it was aimed mostly at professionals.

Some in the wider radical therapy movement quickly articulated displeasure with the Collective's direction. ${ }^{26}$ Many ex-patient groups, deinstitutionalization advocates, and mental health workers felt it had been 'coopted by those who can publicize themselves' - namely the professional class. ${ }^{27}$ The backlash was essentially a by-product of the 'dominance' of the latter; that is, individuals and cliques who possessed 'the resources and know-how' but did not necessarily represent the totality of the movement. ${ }^{28}$ Though 'The Radical Therapist may not have exhibited all or even the most important segments of opinion held by radical psychiatrists, radical therapists, or radical mental health workers... it constitutes their newspaper of record' because of its wide distribution. ${ }^{29}$ The journal served as the primary forum to interpret, reformat, and broadcast anti-psychiatric and radical theories to a larger audience - and because it grew into the movement's chief voice it came to be seen as an establishment organ.

While its twelve issues may not seem momentous, The Radical Therapist dealt with breathtakingly complex topics, captured the diversity of radical thought, and provided a snapshot of radical psychiatry's convolution. Its fire did not last long, but it certainly burned brightly - just as Michael Glenn had hoped. Power and the medical model, mental illness prevention and treatment, psychiatric oppression of minority groups, and psychiatrist-patient relationships were all addressed. Without deviation, authors framed the goal of traditional psychiatry as 'the maintenance of personal and professional power and prestige, economic well-being, and control over others' ${ }^{30}$ Articles in The Radical Therapist also identified the wide-ranging etiological factors that contributed to mental

\footnotetext{
${ }^{25}$ Agel, ed., The Radical Therapist, xiii.

${ }^{26}$ Much the same occurred with the Medical Committee for Human Rights in Boston and New York.

${ }^{27}$ Hurvitz, 'The Status and Tasks of Radical Therapy,' 67.

28 Ibid.

29 John A. Talbott, 'Radical Psychiatry: An Examination of the Issues,' American Journal of Psychiatry 131, no. 2 (1974), 121-122.

30 Ibid.
} 
distress in modern America: not just sexism, racism, militarism, and the consumer economy, but also American schooling, environmental degradation, bureaucracy, and technological growth. ${ }^{31}$ Society truly was sick.

The break that began as early as 1969 in Miami was about to lead radicals down very different paths. Deinstitutionalization was predicated on improving patients' health through more community interaction, increased reliance on anti-psychotic drugs, and, ultimately, was a means to transfer mental health care costs to the federal government. But in a clear allusion to Szaszian theory - specifically, his notion of separating 'psychiatry and the state' - such $R T$ articles as 'Radical overview of community psychiatry' and 'Community mental health as a pacification program,' argued that the average community mental health center was a weapon of the establishment; it acted, in short, as a means to pacify angry communities and promote harmony rather than working toward social change. ${ }^{32}$ Szasz believed that the state, even outside the confines of large asylums, corrupted psychiatry for its own purposes and warped the profession in ways similar to Nazi Germany or the Soviet Union. ${ }^{33}$ Indeed, the statistics on the disproportionate commitment of minorities to American asylums suggested to many that the US was already there: 'In Russia it's a sin to criticize the government, here it's a sin to be poor. ${ }^{34}$ Some, like Jenny Collins of the Alliance for the Liberation of Mental Patients, went further, characterizing psychiatric institutions as 'concentration camps'. ${ }^{35}$ Hyperbole or not, such views made a split more than likely.

\footnotetext{
31 Ibid.

${ }^{32}$ Carl I. Cohen et al., 'The Future of Community Psychiatry,' Community Mental Health Journal 39, no. 5 (2003), 460-462. See Morton O. Wagenfeld and Stanley S. Robin, 'Social Activism and Psychiatrists in Community Health Centers,' American Journal of Community Psychology 6, no 3 (1978), 254 and Rodger Doyle, 'Deinstitutionalization,' Scientific American 287, no. 38 (December 2002): 38.

${ }^{33}$ David J. Rissmiller and Joshua H. Rissmiller, 'Evolution of the Antipsychiatry Movement into Mental Health Consumerism,' Psychiatric Services 57, no. 6 (2006), 864.

34 Susan Stern, 'America's mental hospitals: shock, drugs, surgery,' Seven Days, May 23, 1977, 28, MS 768, Clippings, 1971-1996, Judi Chamberlain Papers, Special Collections and Archives, University of Massachusetts Amherst [hereafter JCP].

${ }^{35}$ Ruth Laughlin, 'A Victory for Mental Patients' Rights: Psychiatric “Treatment,"' 1979, 8, MS 768, Clippings, 1971-1996, JCP.
} 
Radicals also squabbled over the issue of consultation and control in community psychiatry. Initially, according to Madness is Civilization, 'community mental health programs represented a great step forward, especially in light of the evidence...that persons from economically depressed backgrounds suffered far higher rates of psychiatric disorders than persons from affluent communities' ${ }^{36}$ Community services, once touted as a positive outgrowth of liberal Great Society thinking and a departure from what Erving Goffman deemed oppressive asylums, was now targeted by a segment of radical psychiatrists. Community-based psychiatry did little to prevent mental illness, nor did it empower patients. It was a cosmetic alteration that did not change the fundamentals of how individuals were treated by the establishment. Judi Chamberlin, of the Mental Patients' Liberation Front (MPLF), lamented that the media still stigmatized people with mental health problems living in the community as 'faceless, voiceless phantoms'. In her view, ' community care ' was not the entire problem, 'but that greedy businessmen are reaping enormous profits' from providing sub-standard housing to those recently placed in the community. ${ }^{37}$ She was right. In 1978 , The New York Times reported that the state of New Jersey 'doesn't know' what happened to the nearly 40,000 individuals who were 'returned to society' following deinstitutionalization. Many ended up in 'unlicensed homes' where 'the owners frequently pocket Government funds intended for these outpatients. ${ }^{38}$ The system, even in its more benevolent form, continued to oppress those with mental health issues and profit from their suffering.

The radicals ruptured in 1971. The catalyst was the issue of the legitimacy and intransigence of the psychiatric profession and psy-disciplines. Theoretical differences were vital. Yet, disagreement over support for patient activism, accusations of elitism, and a lack of authentic revolutionary action on the part Steiner's Gammas precipitated a split. Some members of Glenn's Collective refuted psychiatry as a valid political activity, repudiating the profession entirely.

\footnotetext{
${ }^{36}$ Michael E. Staub, Madness is Civilization: When Diagnosis was Social, 1948-1980 (Chicago: University of Chicago Press, 2011), 123.

37 Judi Chamberlin, 'Letters: Frontal Assault,' Voice, November 28, 1977, 4, MS 768, Clippings, 1971-1996, JCP.

${ }^{38}$ Daniel Lewis and Milton Leebaw, 'Where Have All The Patients Gone,' The New York Times, March 5, 1978.
} 
Psychiatry and socio-political change were incompatible. Going back as far as 1967-68, radicals had questioned the oppressiveness and mystification of mental health therapies. Now, however, the argument was taken further. Proponents of alternative therapy and ex-patients (a.k.a. 'psychiatric survivors') 'eyed each other with suspicion', the latter coming to 'bar professionals from participating in its conferences, newsletters, and self-help centers'.$^{39}$ Therapists shot back, suggesting that mental patient liberation groups ignored the broader goals of The Left and were too myopic.

A chasm soon separated California's radical therapists from others in the movement, which duly influenced its publications. Acrimony spread, and the Berkeley-based Radical Psychiatry Center, located in the core of psychedelic psychiatry and the emergent New Age mental health environment was singled out as entitled, elitist, and a picture of dilettantish radicalism. Steiner had morphed into a persona non grata for several reasons. Amid bitterness over the Californians' 'middle-class emphasis on groovy fun and individual solutions', Michael Glenn left the journal he had helped found. The last issue of 1971 printed a critique of the journal's title - talk about radical - and was subsequently renamed Rough Times. 'We participate in the world-wide revolutionary force', the newly administered journal held, 'not within the confines of "radicals in the professions"'. ${ }^{40}$ Total revolution was the aim, not simply reform.

Steiner, author of the original Radical Psychiatry Manifesto in 1970, formed another discrete journal, Issues in Radical Therapy. ${ }^{41}$ The break-up was not entirely clean, though, and a degree of animus remained. Rough Times critiqued the break-away therapists thusly:

...most of them are too comfortable in their professionally detached attitudes, pseudo-hip life-styles, and removed position from world revolution as well as personal change. We began to see our position in terms of being part of a

\footnotetext{
${ }^{39}$ Alexander Dunst, Madness in Cold War America (New York: Routledge, 2016), 54.

$40 \mathrm{lbid}$.

${ }^{41}$ Nick Totton, Psychotherapy and Politics (London: Sage Publications, 2000), 28-31.
} 
revolutionary movement. Our goals were more linked to a broad-based socialist movement than to a radical caucus at a professional convention. We began to reassert, with more force and conviction, that RT should be part of a movement to build a revolutionary new world. ${ }^{42}$

The original radicals in mental health were overthrown, but they did not go quietly. Dr. Joy Marcus, who had established herself as a leading radical feminist therapist while in Berkeley, offered a bracing retort. She attacked the change at her former journal as 'depressing, destructive, a rip-off and a cop-out' ${ }^{43}$

The publications continued to diverge. In successive years, both Rough Times and Issues in Radical Therapy (IRT) printed articles. IRT, although a byproduct of discord, regarded itself as constituting part of the same movement; that said, it conceptualized itself as a practically-oriented and prescriptive publication, even as the editors, including Steiner, made clear that any liberal cooptation would be repelled vigorously. Rough Times, for its part, eventually altered its name again - this time to State and Mind. In doing so, the journal completed a journey into the realm of 'selfhelp' and 'pop psychology'. ${ }^{44}$ It ceased publishing and shut down in 1976. IRT offered dense academic articles and came to represent the radical and alternative mental health therapy movement. Its circulation was largely restricted to the Bay Area, completing its run in 1983.

A third publication, Madness News Network (MNN), further complicated the picture. Also based in the Bay Area, it gave voice to ex-patients and the intersecting threads of mental health liberation groups. MNN was founded in 1972 as a newsletter and, while also an outgrowth of political activism and the countercultural strains of the 1960s, it possessed an explicit agenda: tackling the legacy of deinstitutionalization; addressing the failures of preventative measures, community care, and lack of mental health services; and offering a safe 'therapeutic space' for the

\footnotetext{
42 Jerome Agel, ed., Rough Times (New York: Ballantine Books, 1973), i-iii.

${ }^{43}$ Quoted in Totton, Psychotherapy and Politics, 28.

${ }^{44}$ Dunst, Madness in Cold War America, 67.
} 
recipients of services in the system. It solicited its readers' views on the goals, strategies, and tactics to be employed for 'organizing against psychiatry'. ${ }^{45}$ In essence, the editors encouraged readers to 'come out' - to demolish the mystique and fear that often accompanied mental illness.

MNN gradually became a forum for members of New York City's Mental Patients' Liberation Project, Portland's Insane Liberation Front, and San Francisco's Network Against Psychiatric Assault, among others. Unlike its counterparts, Madness New Network tracked closely with civil rights, gay activism, and women's liberation magazines. It aimed to protect the 'rights and dignity of those people labelled crazy'. More than this, and perhaps not surprisingly, MNN leant heavily on Thomas Szasz's ideology. Whereas $R T$ and IRT amalgamated an eclectic group of thinkers, Szasz was preeminent at $M N N$. His strident refusal of 'madness' and casting of psychiatry as a modern religion was apparent in the journal from its inception. Indeed, this outlook - stressing individualism and denial of mental illness - underpinned much of $M N N^{\prime}$ s political activity. ${ }^{46}$ As $M N N^{\prime}$ s readership grew, so too did its influence and contributors included such eminent thinkers as Frantz Fanon.

\section{Activated Patients}

Psychiatric survivor movements, according to historian Geoffrey Reaume, failed to achieve the level of support of black civil rights or anti-Vietnam protestors, however, they exerted a tangible influence on mental health policy and terminology.$^{47}$ Ex-mental patients' interest groups organised protest demonstrations, circulated petitions, conducted lobbying activities, and initiated legal proceedings against psychiatrists and institutions. ${ }^{48}$ The Insane Liberation Front (ILF), established in Oregon in June 1970 , lasted only six months, but its principal objective-to disassemble the psychiatric institution-was documented in the pages of radical psychiatry articles. A second group, the Mental

\footnotetext{
45 MNN letter to subscribers, July 29, 1975, MS 768, Series 2, Box 6, Conference on Human Rights and Psychiatric Oppression, Third, 1975, JCP.

${ }^{46}$ Thomas Szasz, Coercion as Cure: A Critical History of Psychiatry (New Brunswick: Transaction Books, 2010).

${ }^{47}$ Geoffrey Reaume, 'Lunatic to patient to person: Nomenclature in psychiatric history and the influence of patients' activism in North America,' International Journal of Law and Psychiatry 24, no. 4 (2002), 415-417.

${ }^{48}$ Hurvitz, 'The Status and Tasks of Radical Therapy,' 67.
} 
Patients' Liberation Project (MPLP), was founded in New York City in 1971 by a former ILF member and opposed involuntary treatments, including forced hospitalization, electroshock, aversive behaviour therapy, and psychosurgery. ${ }^{49}$ That year, the Mental Patients' Liberation Front (MPLF) was established in Boston. In 1972, San Francisco gave rise to the Network Against Psychiatric Assault (NAPA). Patients were activating and organizing all across the country and many ex-patient members of these separate organizations believed that mental illness was a social construction..$^{50}$ If they could prevent elites from infiltrating their movement, they could prevent mental illness from proliferating by refusing to cooperate with the propagators of such a harmful idea as 'madness'.

The ex-patients' movement was far from a static group and adopted various names, including the 'anti-psychiatry', 'mad liberation', 'mental health consumer', and 'psychiatric survivor' movement. The term 'inmate' was employed, as was 'client' and 'consumer', among others. Overall, the movement eschewed distinct leadership, not to mention goals, objectives, or formal membership. Empowerment and self-ownership were what mattered, in addition to protecting individuals who had experienced the mental health establishment. These 'non'-members militated against oppression. Actions took the form of forums, protests, press conferences, and publications. Judi Chamberlin's On Our Own: Patient-Controlled Alternatives to the Mental Health System, was published in 1978 to much acclaim. It would later be hailed as the movement's Bible/Koran/Talmud/Vedas/I Ching. Was there a glue for the movement? If anything, the loose collection of organizations spread across the country communicated through Madness News Network. As Chamberlin put it: 'In various places across North America there are even single,

\footnotetext{
${ }^{49}$ The name of the MPLF's house publication, 'Free Expression,' reflected its desire to help ex- and current patients 'fight for our personal liberty'. 'Free Expression,' MS 768, Clippings, 1971-1996, JCP.

${ }^{50}$ Chamberlin, 'The Ex-Patients' Movement.' See also Lucas Richert, '“Therapy Means Change, Not Peanut Butter": Radical Psychiatry in the United States, 1967-1975,' Social History of Medicine 27, no. 1 (2014): 104121.
} 
isolated individuals who are genuine participants in our movement. ${ }^{\prime 51}$ Additionally, the first annual Conference on Human Rights and Psychiatric Oppression was held in 1973.

In San Francisco, the Network Against Psychiatric Assault (NAPA) constituted the leading wing of the movement. After its formation in 1974, NAPA targeted the Langley Porter Hospital at the University of California, San Francisco, Herrick Memorial Hospital in Berkeley, and the McAuley Neuropsychiatric Institute in St. Mary's Hospital in San Francisco. NAPA opposed the use of electroconvulsive therapy (ECT) in each of these institutions, where it was often undertaken involuntarily or without informed consent. Members invaded locked wards at McAuley to protest involuntary drugging and opposed the startling practice of 'sheeting', wherein uncooperative patients were swaddled - or mummified - as a means of punishment. The Proud Paranoid Theatre Troupe even performed a pantomime 'guerilla version of the sheeting technique'.${ }^{52}$ NAPA targeted specific psychiatrists who frequently used ECT and proceeded to protest/disrupt their offices and organized a sleep-in at Governor Edmund G. Brown Jr.'s office in Sacramento. ${ }^{53}$

Patient activists, as distinct but interconnecting groups, displayed the squabbling that troubled radical mental health practitioners. The Third Annual Conference for Human Rights and Against Psychiatric Oppression, held in San Francisco in 1975, proved to be a flashpoint. Sick of elitism, tired of being second-class participants in the movement, ex-patients held protests at St. Mary's Hospital, and then gathered at San Francisco's Union Square. They roared, 'Smash the Therapeutic State!' They yelled, 'What do you want? Freedom!' Such emotion was a powerful force in the fight against psychiatry. Describing the conference, one participant stated that it:

\footnotetext{
51 Handwritten note, undated, MS 768, Series 2, Box 6, Conference on Human Rights and Psychiatric Oppression, Fifth, 1977, JCP.

52 Hera Goldman, 'Psychiatric Assault,' MS 768, Clippings, 1971-1996, JCP.

${ }^{53}$ Patria Joanne Alvelo, 'The Politics of Madness: The Women's Liberation Movement in the 1970s,' (MA diss., Sarah Lawrence College, 2009); Judi Chamberlin, 'Organizing,' 4, cited in Lenny Lapon, Mass Murderers in White Coats: Psychiatric Genocide in Nazi Germany and the United States (Springfield: Psychiatric Genocide Research Institute, 1986), 170.
} 
...was just like MPA in a lot of ways-fuzzy, no focus, lots of non-patients...putting down anger as "not nice." No, anger is not "nice," but it's real, it comes from the gut, and not to be angry at being shit upon is being dead-which is what shrinks and their kind what [sic] us all to become. That's why they lock us up, drug us, cut into our brains with electricity and with knives...because our anger is POWER, and THEY ARE AFRAID OF US. And anyone who is not angry at what they do to usis [sic] as much our enemy as the shrinks themselves. ${ }^{54}$

A full-on fracture occurred on the final day of the conference, which carried over into subsequent years: the ex-patients shut practitioners out. The simple act of slamming the door to outsiders-especially professionals in the psy-sciences, even if they did call themselves radical-was a means to empower ex-patients and embrace their own expertise. It signaled recognition of the divide between service providers and patients and of entrenched inequalities. Indeed, many expatients felt they were the true authorities on mental health and derided the hip professionals, an epithet that gained momentum in 1975, the same year One Flew Over the Cuckoo's Nest hit theatres. Of the 'hip shrinks [and] therapists' wanting to attend, they asked: 'Who are they? + What for? At our conference?"55 Their 'whole idea of "objectivity"' served 'to deemphasize and discredit the passion and anger' of conference participants. ${ }^{56}$ Chamberlin, for her part, thought that allowing professionals to attend would give ex-patients the opportunity to vent their frustration: 'The meetings provide a chance for the movement to make clear to these people that ex-inmates are angry, and that we demand the right to speak for ourselves. ${ }^{57}$ But, drawing on Black Power and radical feminism strategies, some ex-patient activists felt separation was often the best way to advance their goals. Breaking away from the mental health system's agents would create a space in which they might achieve their ends. Did it make sense to ally with psychiatrists or psychologists

\footnotetext{
${ }^{54}$ Anonymous to Tom, July 19, 1975, MS 768, Series 2, Box 6, Conference on Human Rights and Psychiatric Oppression, Third, 1975, JCP.

55 Mabel to Judi Chamberlin, January 4, 1976, MS 768, Series 2, Box 6, Conference on Human Rights and Psychiatric Oppression, Fourth, 1976, JCP.

56 'Fighting Psychiatric Oppression,' MS 768, Series 2, Box 6, Conference on Human Rights and Psychiatric Oppression, Third, 1975, JCP.

57 Judi Chamberlin letter to members, June 8, 1978, MS 768, Series 2, Box 6, Conference on Human Rights and Psychiatric Oppression, Sixth, 1978, JCP.
} 
when the aim was a complete abolition of therapeutic intervention? Many thought not. ${ }^{58}$ Preventing mental illness meant, in part, preventing professionals diagnosing such illnesses in the first place. The ex-patients secluded themselves the following year.

In 1976, during the next year's conference, ex-patients held meetings apart from the other participants, placing 'Keep Out' signs on the doors. If one had not spent some time in a mental institution, then stay away. Professionals like the Radical Caucus members from Berkeley were consequently put in a position of self-justification, even feeling wounded. One clinical psychologist, Michael D. Galvin, was 'hurt and angry' at being excluded, but wanted to be involved in future projects. ${ }^{59}$ Judi Chamberlin replied that 'The presence of someone who presents himself as superior, detached, and professional (as you do) would be most unhelpful.' The conference was for 'former mental patients' who 'want to fight back', not professionals 'with the full intention of being leaders' ${ }^{60}$ Galvin was piqued:

Your letter was a perfect example of the zeal found in the early phases of liberation movements. It enhances cohesion and the general energy level, but unfortunately seems to go hand in hand with a non-differentiation of targets of anger...You called me "superior, detached, and professional"...I think I am superior in my clinical abilities...and I am professional in the best sense of the word. ${ }^{61}$

\footnotetext{
${ }^{58}$ See, for example, the Mental Patients' Liberation Project's call for 'no less than [Institutional Psychiatry's] abolition' in Tony Colletti, 'The Jailers of the People,' MS 768, Clippings, 1971-1996, JCP.

${ }^{59}$ Michael D. Galvin, Ph.D. to Judi Chamberlin, May 6, 1976, MS 768, Series 2, Box 6, Conference on Human Rights and Psychiatric Oppression, Fourth, 1976, JCP.

60 Judi Chamberlin to Michael D. Galvin, Ph.D., May 14, 1976, MS 768, Series 2, Box 6, Conference on Human Rights and Psychiatric Oppression, Fourth, 1976, JCP.

${ }^{61}$ Michael D. Galvin, Ph.D. to Judi Chamberlin, May 19, 1976, MS 768, Series 2, Box 6, Conference on Human Rights and Psychiatric Oppression, Fourth, 1976, JCP.
} 
He still believed some good could come of the conference, but did not understand why he should be barred. After all: 'I do subscribe to the R.T. [The Radical Therapist] and have long been a member of the ACLU which both do support your cause. ${ }^{62}$ This exchange was a preview of what was to come.

According to Chamberlin, the separation had led to 'noisy confrontations' both within and without the community. She despaired that the conflict had signaled a missed opportunity to confront the 'hip professionals', to discuss 'real alternatives', and challenge 'those who made money off human suffering while presenting themselves as radicals' ${ }^{63}$ But professionals were not totally locked out. NAPA staff indicated that, for their 1977 conference, 'professionals will be allowed to attend...only if they have been specifically endorsed by an ex-inmate/anti-psychiatry group' ${ }^{64}$ Even within these safe spaces there were tensions, with one male participant at the 1977 Boston conference claiming: 'The anti-male sentiment had a strong undercurrent and I wasn't prepared...therefore got overly humiliated. ${ }^{\prime 65}$ Chamberlin thought the 'movement is very open, very fluid', but she herself came to be accused of elitism. In self-accusatory language she posited that 'maybe I'm just blind to it'. ${ }^{66}$ The limits of these radical partnerships had clearly stretched to the breaking point. It was not only professionals who were not welcome in the movement, but putative leaders and fellow-travelers too.

\section{Conclusion}

Radicals within the psychiatric establishment acknowledged that they needed to adapt to the modern world, but erstwhile allies and critics in the anti-psychiatry movement would brook no compromise with what they saw as a set of oppressive institutions and practices. Like Peter Finch,

\footnotetext{
62 Ibid.

63 Lapon, Mass Murderers in White Coats, 171.

${ }^{64}$ Letter to Chamberlin, 1977, MS 768, Series 2, Box 6, Conference on Human Rights and Psychiatric Oppression, Fifth, 1977, JCP. This policy was carried over into the 1978 conference. See Letter from The Alliance For the Liberation of Mental Patients to members, April 5, 1978, MS 768, Series 2, Box 6, Conference on Human Rights and Psychiatric Oppression, Sixth, 1978, JCP.

${ }^{65}$ Lew Eli Budd to Judi Chamberlin, June 15, 1977, MS 768, Series 2, Box 6, Conference on Human Rights and Psychiatric Oppression, Fifth, 1977, JCP.

66 'Frustration in Philadelphia by Judi Chamberlin,' undated, 3, MS 768, Series 2, Box 6, Conference on Human Rights and Psychiatric Oppression, Sixth, 1978, JCP.
} 
playing the radical newscaster Howard Beale in 1976's Network, they exhorted their fellows to act. Get out, protest, and prevent injustice. Beale's call could easily have been uttered by activists in the movement: 'I'm a human being, goddammit! My life has value!...I'm as mad as hell and I'm not gonna take this anymore!' And, in acting outside of the traditional avenues of change within the medical establishment, they didn't. Unfortunately, their inability to unite curbed the impact of their agitation.

After analyzing The Radical Therapist and alternative mental health more broadly, psychiatrist John Talbott suggested that members of the radical Collective were divided into those 'who want to effect change and those who are nihilistic "neo-dadaists."'67 To be sure, radicals in the field of mental health had always demonstrated a multi-faceted ideology, and the brief history of The Radical Therapist not only captured the exertions particular to harmonizing such a broad set of ideas, but also tested the limits of the radicals' tolerance for each other. They called each other names. They accused one another of capitulation. Radical psychiatrists, in short, represented the complications and catches inherent in negotiating the mishmash of theories and ideas of Laing, Goffman, and Szasz, among others. Contending with and reconciling concepts about the politics of experience, the dangers of asylums, as well as myths of mental illness and state control was not a simple task. Such difficulties were manifest in the pages of The Radical Therapist. While certain radicals advocated modifying how community psychiatry was conducted, others suggested that this practice was another mode of state control.

Difficulties in streamlining radical theory were also present in radicals' association with patient survivors. The belief in professional boundaries between physician and patient prevented some psy-professionals, even though they considered themselves radical, from coming together. By contrast, others felt those boundaries were artificial, injurious to the patient, and required total

\footnotetext{
${ }^{67}$ Talbott, 'Radical Psychiatry,' 126.
} 
demolition. ${ }^{68}$ Likewise, involuntary hospitalization, psychoactive drugs, electroshock, behaviour modification, and psychosurgery all served to split radical psychiatrists. In the end, radical psychiatry, even as it recast older theories, coalesced, and splintered, was 'ideologically all over the map' ${ }^{69}$ From its inception in 1968, radicalism proved to be an intricate and incompatible mixture of ideas and a straightforward anti-psychiatry classification does not adequately encapsulate the complexity of the movement. It sought social transformation, but it also unwittingly contributed to the rise of popular self-help psychology, blended with New Age ideas regarding the mind and body, and changed the relationship between citizen and government. Prevention thus became the remit of the individual.

The eventual buckling of the radical movement was caused by various weights and tensions. A number of radicals advocated wholesale commitment to social revolution in the belief there would be no mental illness in utopia. Others wanted to focus on reforming psychiatry itself, rather than sidelining it in favor of political action. Several radical articles, which proposed a Bill of Rights, agreed with the Insane Liberation Front and called for the comprehensive dismantling of the capitalist system, mental institutions, mental commitments, and the practice of psychiatry more broadly. By contrast, other articles in The Radical Therapist concurred with the moderate MPLF, led by Chamberlin, advocating reform of mental health practices. ${ }^{70}$ While there may have been some agreement between professional psychiatrists, psychologists, and patients groups, there was little uniformity regarding the appropriateness of their association. Some believed that former mental patients and professional therapists should collaborate directly while others felt that they could 'work together but not in the same organization'. Similarly, most radicals considered 'involuntary

\footnotetext{
68 Hurvitz, 'The Status and Tasks of Radical Therapy,' 68.

69 Staub, Madness is Civilization, 5.

70 Quoted in Talbott, 'Radical Psychiatry,' 124-125. See 'Insane Liberation Front,' edited by Agel, The Radical Therapist, 2 and 15; 'Mental Patients' Liberation Front: Statement,' in ibid, 2, and 24.
} 
hospitalization, psychoactive drugs, electroshock, behavior modification, and psychosurgery as harmful', yet others regarded such treatments 'as useful in specific instances'. ${ }^{71}$

For some radical psychiatrists it was necessary to dismantle the domineering psychiatric profession-a monolithic, conservative structure-and at the same time impose constraints on the imperialistic expansion of psychiatry; for others, reform was the ultimate goal. The radical psychiatry ideology, in short, embodied both positive and reformist sentiments and anarchistic and nihilistic viewpoints. In Mark Kurlansky's interpretation of radicalism in 1968 and beyond, he writes, "ideologies were seldom clear, and there was widespread agreement on very few issues." ${ }^{72}$ Radicals in mental health were similarly divided. Though they agreed on the need to transform psychiatry, few saw eye to eye on what that meant and how it was to be done. Psychiatrists wanted to prevent society from succumbing to its sickness, while those in the anti-psychiatry movement sought to prevent mental illness from increasing its capacity for oppression.

\footnotetext{
${ }^{71}$ Hurvitz, 'The Status and Tasks of Radical Therapy,' 68.

72 Mark Kurlansky, 1968: The Year that Rocked the World (New York: Ballantine, 2004), xvii.
} 